\title{
Home country bias: Does domestic experience help investors enter foreign markets?
}

\author{
Margarida Abreu ${ }^{a}$, Victor Mendes ${ }^{\text {b,* }}$, João A.C. Santos ${ }^{c}$ \\ a Instituto Superior de Economia e Gestão, Rua Miguel Lupi 20, 1200 Lisboa, Portugal \\ ${ }^{\mathrm{b}}$ CMVM-Portuguese Securities Commission Avenida da Liberdade 252, 1250 Lisboa, Portugal \\ ${ }^{\mathrm{c}}$ Federal Reserve Bank of New York, 33 Liberty St. New York, NY 10045 United States
}

\section{A R T I C L E I N F O}

\section{Article history:}

Received 11 December 2009

Accepted 25 January 2011

Available online 5 February 2011

\section{JEL classification:}

G11

G15

F30

Keywords:

Learning

Home country bias

Duration analysis

\begin{abstract}
A B S T R A C T
This paper investigates the dynamics of individuals' investments leading up to their decision to make the first investment abroad. We show that investors first invest in domestic securities and only some time later they invest abroad in foreign securities. We also show that investors who trade more often in the domestic market start to invest abroad earlier. Our findings suggest that the experience investors acquire while they trade in the domestic market is a key reason why active investors enter the foreign market earlier. A reason is that highly educated investors as well as investors with more financial knowledge, arguably those for whom learning by trading is the least important, do not need to trade as much in the domestic market before they start investing in foreign securities. Another reason is that investors who start investing in foreign securities are able to improve on their performance afterwards. This improvement in performance constitutes further evidence that the home country bias is costly.
\end{abstract}

(c) 2011 Elsevier B.V. All rights reserved.

\section{Introduction}

The home country bias remains one of the most important puzzles in international finance. The relatively low correlation between stock returns of various countries and the potential benefit from international diversification have been known for decades. ${ }^{1}$ Yet, the vast majority of investors still do not invest in foreign securities or only hold a very small portion of their portfolios in foreign securities. By investing largely in their home country, investors may accept a far from optimal combination of portfolio return and risk. In this paper, we attempt to contribute to the literature on home country bias by investigating the dynamics of individuals' investments leading up to their decision to make the first investment in foreign equities abroad. Our objective is to find out if investors' experience in the domestic market accelerates their decision to "enter" foreign markets and whether this decision affects their performance.

It is by now well established that investors tend to overweight domestic equities and underweight international equities when they select their investment portfolios. ${ }^{2}$ French and Poterba

\footnotetext{
* Corresponding author. Tel.: +1 351 213177000; fax: +1 351213537077.

E-mail addresses: mabreu@iseg.utl.pt (M. Abreu), victormendes@cmvm.pt (V. Mendes), joao.santos@ny.frb.org (J.A.C. Santos).

1 See, for example, Levy and Sarnat (1970).

2 Researchers have found other forms of "home" bias. Coval and Moskowitz (1999), for instance, find that US fund managers exhibit a strong preference for firms with local headquarters. Huberman and Sengmuller (2004), in turn, find that employees tend to invest a large proportion of their retirement plans in their own company's stock.
}

(1991), for example, document that the fraction of US equity portfolios invested abroad is very small. ${ }^{3}$ Oehler et al. (2008) provide evidence of home country bias among German investors, and Karlsson and Norden (2007) provide similar evidence among Swedish investors. This bias also appears to extend to Portugal, the country of origin of our data, since only $4 \%$ of Portuguese investors have investments in foreign securities. ${ }^{4}$

There is also evidence that home country bias is costly. Lewis (1999), for example, shows that there are substantial gains when moving from investing fully in the S\&P 500 index to a partial investment in a fund that emulates the MSCI Europe, Australia and Far East index. Bailey et al. (2008), in turn, show that the mean monthly portfolio return of foreign-inclined investors is only slightly higher than that of their domestic benchmarks, but the later investors experience a much higher volatility and lower Sharpe ratios.

Given the benefits from investing in foreign securities, the natural question to ask is why so few investors pursue these investments? Researchers have proposed several explanations for the home country bias. Cooper and Kaplanis (1994), for example, suggest that this bias arises because home assets provide better hedges against country specific risks. Kang and Stulz (1997), in turn, claim it arises because the costs of international diversifica-

\footnotetext{
3 For more recent evidence on US investors' home country bias see, for example, Campbell and Kráussl (2007), and Kho et al. (2009).

4 This figure includes direct investments in individual foreign securities, investments in ADRs and investments in mutual funds that invest in foreign securities.
} 
tion exceed the corresponding gains, whereas French and Poterba (1991) argue that it results from systematic differences in return expectations across investors. Graham et al. (2005) put forth an explanation based on investors' competence. They suggest that investors are willing to invest in foreign securities only after they fill competent about the benefits and risks involved in these investments. Lastly, Strong and Xu (2003) provide a behavioral explanation for the home country bias: this bias arises because investors tend to be more optimistic towards home markets than towards international markets. ${ }^{5}$

Researchers have found supporting evidence for some of these theories. ${ }^{6}$ Graham et al. (2005), for instance, find that investors with more competence are more likely to invest in international assets. Vissing-Jorgensen (2003) finds that high wealth households are more likely to invest in foreign securities, and argues that this is consistent with high wealth households paying the information cost associated with investing in foreign assets. Strong and Xu (2003) find that investors are more optimistic towards their home markets than they are about foreign markets.

In this paper, we attempt to add to this literature by investigating whether investors' domestic experience help them invest for the first time in foreign securities abroad. We start out by documenting that there is a "life cycle" effect in individuals' investment choices in the sense that investors first invest in domestic securities and only some time later they invest in foreign securities. We then use duration analysis to investigate if investors' domestic trading experience affects the length of time it takes them to start investing abroad. We investigate the effect of domestic trading on the timing of the decision to enter foreign markets controlling for a set of factors the previous studies find help explain the home country bias.

Our findings show that ceteris paribus investors who trade more often in the domestic stock market wait a shorter period of time before they start to invest in foreign securities abroad. Our findings also show that married and female investors as well as older investors wait a longer period of time before they start investing in foreign securities. In contrast, wealthier investors, as well as investors with more education and those with access to more financial information start to invest in foreign securities earlier. Lastly, we find that performance in the domestic market has a nonlinear effect investors with the worst performance as well as those with the best performance wait for a shorter period of time before they start investing in foreign securities.

In the second part of our paper, we try to explain why investors who trade more often in the domestic market tend to enter the foreign markets earlier. This finding is unlikely the result of an investment strategy which picks stocks randomly because investors in our sample need to invest abroad in order to acquire foreign securities. $^{7}$ We posit two hypothesis for our finding. Following Nicolosi et al. (2009) and Seru et al. (2008), who show that investors learn by trading, we conjecture that investors who are active in the domestic market learn faster the advantages of investing in foreign securities and consequently start investing abroad earlier. Following

\footnotetext{
${ }^{5}$ Other explanations for the home country bias, as reviewed in Lewis (1999), include barriers to international investments, such as international taxes and government capital restrictions, information asymmetries between domestic and foreign markets (investing in foreign equity markets may require understanding foreign accounting standards and legal environments), and the prevalence of closely held firms in most countries causing the world float portfolio to be significantly different from the world market portfolio.

6 Several empirical studies, including Cooper and Kaplanis (1994) and Baxter and Jermann (1997), argue that the effects detected in this literature are too small to account for the degree of home bias observed in the data.

7 Since we want to focus on foreign investments, we left out from our sample those investors who invest in ADRs. This does not have any material effect on our findings because only a tiny number of ADRs trade in the Portuguese stock exchange.
}

Odean (1999) and Barber and Odean (2000, 2002), who argue that investors tend to trade too often because they are overconfident, we conjecture that investors who are active in the domestic market are overconfident and their pursue of new trading opportunities leads them to enter foreign markets earlier.

Our results generally support the learning explanation but not the overconfidence explanation. A reason is that we find that highly educated investors as well as investors with more financial knowledge, arguably those for whom learning by trading is the least important, do not need to trade as much in the domestic market before they start investing in foreign securities. Similarly, we find that investors who enter the foreign market by making their first investment in Spain, probably the country with the closest cultural affinity with Portugal, also do not need to trade as much in the domestic market before they go abroad. Another reason is that these results continue to hold when we account for overconfident investors. Finally, and still in support of the learning explanation and contrary to the overconfident explanation, we find that investors who enter the foreign markets are able to improve on their performance afterwards.

Our paper adds to the literature on home country bias in some important ways. Our investigation of the dynamics of individuals' investments leading up to their first investment in foreign securities is novel. Understanding investors' decision to undertake this investment is valuable because it is arguably the most important decision they make once they decide to pursue the potential benefits from investing abroad. Our focus on individual investors (as opposed to institutional investors) and on their investments on individual securities made abroad (as opposed to investments in mutual funds of foreign securities or in ADRs) is also important because it requires more expertise and it is more revealing of investors' intent to pursue the potential benefits from foreign investments. ${ }^{8}$ Our finding that investors learn while they trade in the domestic market and this helps them accelerate their decision to start investing in foreign securities adds support to Graham et al. (2005) competence theory for the home country bias, and suggests that programs aimed at improving investors' financial literacy could help reducing this bias. Further, our finding that investors who enter the foreign markets are able to improve on their performance afterwards confirms that there are gains for investors from entering the foreign markets earlier, and corroborates Lewis (1999) and Bailey et al.'s (2008) finding that the home country bias is costly.

Our findings also parallel evidence uncovered in the international literature on the internationalization of firms. ${ }^{9}$ Our evidence on the dynamics of investors' choices showing that investors start to trade in the domestic market and only some time later they enter the foreign markets, for instance, parallels the Uppsala school of internationalization's insight that firms' internationalization is a stepwise process: firms begin their activity in the domestic market before they penetrate foreign markets. ${ }^{10}$ Our finding that more active investors in the domestic market start to invest in foreign firms earlier, in turn, parallels the evidence in international trade literature that more active and productive firms go abroad first. ${ }^{11}$

The remainder of the paper is organized as follows. The next section presents our methodology and our data sources. This section also characterizes our sample. Section 3 presents our results on

\footnotetext{
8 Bailey et al. (2008), Graham et al. (2005) and Karlsson and Norden (2007) all investigate the home country bias based on data on individuals' portfolios. However, in Bailey et al. (2008) investors invest in foreign securities through ADRs which enable US investors to buy shares in foreign companies without undertaking crossborder transactions. Graham et al. (2005) use a survey, not actual trading data and Karlsson and Norden (2007) study portfolios which are formed as a part of the pension plan in Sweden, not direct investments in foreign equities.

${ }^{9}$ We thank the referee for calling our attention to this parallel.

10 See Johanson and Vahlne (1977).

11 See, for example, Helpman et al. (2004)
} 
the importance of domestic experience for investors' decision to invest for the first time in foreign securities. Section 4 presents the results of the tests we undertake to explain why investors who trade more often in the domestic market start to invest in foreign securities earlier. Section 5 concludes the paper with some final remarks.

\section{Methodology, data, and sample characterization}

\subsection{Methodology}

Our methodology has two parts. The first part attempts to investigate if investors' trading activity in the domestic market is important at reducing their home country bias in the sense of accelerating their decision to start investing in foreign securities. The second part attempts to test some hypotheses we put forth to explain the link we identify between trading in the domestic market and the time it takes investors to start investing in foreign securities.

\subsubsection{Do active traders go abroad earlier?}

The first part of our methodology relies on duration analysis which is often used to study problems that involve the passage of time before a certain event occurs. In our study, the event of interest is investors' first investment in a foreign security. We want to find out if the length of time it takes investors to start investing abroad since they start trading in the domestic stock market is driven by their trading activity in the domestic market. Duration analysis enables us to characterize the process of investors' first investment abroad more rigorously than a logit or probit regression analysis because these models can only deal with the dichotomy occurrence/ nonoccurrence of the event. Furthermore, duration analysis is more adequate to handle time-varying explanatory variables and to accommodate data censoring. ${ }^{12}$ These aspects of the duration analysis are important for our investigation because some of our controls vary over time. In addition, while we do not have a left-censoring problem because we have complete information about the trading history of investors, we do need to account for right-censoring given that by the end of the sample period not all investors in the sample have made an investment in a foreign security.

Traditional duration analysis assumes a distribution for the duration and uses maximum likelihood to estimate the effect of regressors on the expected duration. However, to avoid making specific assumptions about the shape of the hazard function we consider a semi-parametric approach to investigate the determinants of the hazard rate. We follow Cox (1972) who proposed a partial likelihood method (rather than a maximum likelihood) to estimate the slope coefficients $\beta$ in a proportional hazard specification for the hazard function such as:

$h\left(t \mid x_{t}\right)=h_{0}(t) \exp \left(\beta^{\prime} x\right)$,

where $h_{0}(t)$ is the baseline hazard, which is common to all units of observation, $x$ is a vector of regressors and $\beta$ is the vector of parameters. Taking logs to both sides of Eq. (2) we have:

$\log \left(h\left(t \mid x_{t}\right)\right)=\log \left(h_{0}(t)\right)+\beta^{\prime} x$.

We can easily see that $\beta_{j}$ measures the semi-elasticity of the hazard with respect to $x_{j}$. In the above specifications, the vector $x$ is constant but the Cox model can also handle time-varying explanatory variables. ${ }^{13}$

\footnotetext{
$\overline{12}$ A typical survival time data set contains both spells for which entry and exit dates are observed as well as right censored incomplete spells. A survival time is said to be right censored when, at the time of observation, the relevant event has not yet occurred, so the total length of time between entry and exit is not known exactly.

13 Despite the fact that most relevant variables change with duration, in some cases they change at a slower pace than a typical duration. For that reason, they are often treated as if they were constant. See Lancaster (1990), p. 21.
}

As we noted above, our key objective is to investigate whether investors' trading experience in the domestic market, which we measure by the log of the number of trades in securities in each quarter, LTRADES, accelerates their decision to start to invest abroad. We investigate this effect controlling for a set of factors which researchers have found to help explain home country bias. As many of these factors change with time, we estimate our models with time-varying explanatory variables. We provide different values for our explanatory variables for each interval between $t=0$ and $t=t i$, the terminal point at which exit or censoring takes place. ${ }^{14}$ The time interval that we consider in our analysis is the quarter. In the Robustness section we discuss what happens when we use the year interval instead.

Following Karlsson and Norden's (2007) finding that demographical features help explain the home country bias, we control for investors' gender and marital status by including the dummy variables MALE and MARRIED, respectively, and for investors' age, $A G E$, as of the beginning of their trading activity. Following Graham et al. (2005) finding that more competent investors are more likely to invest in foreign securities, we control for the education of investors by including dummy variables to distinguish investors with high education, HIGH EDU, from those with intermediate education INTERMEDIATE EDU, and those with basic education, BASIC EDU. Following Vissing-Jorgensen (2003) finding that wealthy investors tend to hold more foreign assets we attempt to control for investors' wealth by controlling for their job (our closest proxy for wealth). To that end, we use dummy variables to identify inactive investors, INACTIVE, and investors with a highly skilled job, HIGHLY SKILLED, and those with a skilled job, SKILLED. We further control for whether the investor has a time deposit, TIME DEPOSIT, and whether the investor has a mortgage, MORTGAGE, and a consumer loan, CONSUMER LOAN, as these will likely affect his wealth. Following Kilka and Weber (2000) and Strong and Xu (2003) finding that investors are more optimistic towards their home markets, we control for the net performance of the European markets over the Portuguese stock market, EUROPEAN RET. Finally, we control for investor' residence since investors who live in the metropolitan areas are usually more educated and are more likely to be wealthier and employed in the financial sector and consequently to have access to better quality information. To that end we distinguish investors who reside in Lisbon, LISBON, from those who reside in Oporto, OPORTO, which are the two largest cities in the country, from investors who reside elsewhere, OTHER.

In the Robustness section, we investigate whether our finding on the importance of domestic trading for entering continues to hold when we control for a set of other factors that could affect investors' decision to invest in foreign securities, including whether investors have made investments in derivatives, DERIVATIVES, investments in mutual funds of domestic securities, MUTUAL $F U N D S_{D}$ or in mutual funds of foreign securities, MUTUAL FUNDS . Controlling for investors' investments in funds is important because we define the timing of investors' entry abroad based on their investments in individual foreign stocks. Since derivatives tend to be complex financial instruments, we expect that investors who make investments in these assets to be more sophisticated and consequently to start investing abroad earlier. Similarly, since investments in mutual funds of foreign securities require more information and probably more expertise than investments in domestic stocks, we expect that investors who make investments in foreign mutual funds to start investing abroad earlier. On the other hand, some of these investors may see these funds as a

\footnotetext{
14 See Lancaster (1990), p. 23, for a discussion of some of the issues associated with these models.
} 
substitute for their investments in individual stocks abroad. So, investors with stakes in foreign mutual funds may choose to start investing in foreign stocks earlier or later than the remaining investors. In contrast, since investments in mutual funds of domestic securities require the least information and expertise, we expect that investors with stakes in these mutual funds to wait longer before they start investing abroad.

Following Beugelsdijk and Frijns (2010) and Anderson et al. (2011) finding that cultural affinity plays an important role on investors' choice of the foreign markets, where they make their investments, we control for those investors who make their first investment abroad in Spain, arguably the foreign country that Portuguese investors have the highest cultural affinity. ${ }^{15}$ To this end, we define the dummy variable SPAIN, which equals one for those investors who make their first investment abroad in a stock of a Spanish company.

Finally, we investigate the robustness of our finding when we account for investors' performance in the domestic stock market. Investors who perform poorly in the domestic market may have added incentives to start investing abroad in an attempt to improve on their performance. On the other hand, to the extent that domestic performance signals investors' capabilities and expertise in making the right investments, those investors that do well at home may be more capable and consequently start investing abroad earlier. We attempt to account for these differences by controlling for a set of dummy variables, PERFORMANCE $E_{\mathrm{Q} i}$, one for each quartile of the distribution of investors' performance in the domestic market. We follow Seru et al. (2008) and measure the performance of investors by the 30-day average return of stocks purchased in each quarter. This is a measure of investor performance in the sense that it captures the investor ability to make good investment choices.

\subsubsection{Why do investors go abroad?}

The second part of our methodology attempts to identify the reason(s) behind the link we identify between trading in the domestic market and the time it takes investors to start to invest abroad. We focus on two potential explanations for that link. Following the studies by Nicolosi et al. (2009) and Seru et al. (2008), who show that investors learn by trading, we posit that investors who trade more often in the domestic market enter earlier in the foreign market because of the experience they accumulate while trading in the domestic market. If this is the explanation for our finding, then we expect domestic trading to be more important for those investors who can learn the most with trading experience, in other words less educated investors and investors with less financial knowledge and financial information.

To investigate this hypothesis, we start by identifying those investors with a college degree, HIGH EDU, investors that are more likely to have financial knowledge because they trade on derivatives, DERIVATIVES, and investors that are more likely to be financially educated, LITERACY, because they are economists, managers or employees of banks. Next, we expand our duration model to include the interaction of these dummy variables with investors' domestic trading activity, LTRADES. If investors learn while they trade in the domestic market and this helps them enter abroad, then we would expect our proxies for investors' knowledge and financial education to have a positive sign and their interaction with investors' domestic trading activity to have a negative sign.

As a complement to these tests, we investigate whether investors who enter the foreign market by investing in Spanish compa-

\footnotetext{
15 The other foreign country candidate to this classification is Brazil, but during the sample period concerns with foreign exchange risk and political risk deterred foreigns from making investments in that country.
}

nies do not need to trade as much as investors who enter by investing in companies of other countries. To this end, we extend our duration model and add the dummy variable we define to identify investors who make their first foreign investment in a Spanish company, SPAIN, and the interaction of this variable with our measure of investors' domestic trading activity, LTRADES. If investors learn while they trade in the domestic market and this helps them go abroad, since Portuguese investors have the highest cultural affinity with Spain, then we expect them not requiring as much domestic trading before they start making investments in Spanish companies. In other words, we expect the dummy variable SPAIN to have a positive sign and the interaction of this variable with LTRADES to have a negative sign.

An alternative explanation for our finding is that active investors in the domestic market start investing abroad earlier because these investors are overconfident. The literature on behavioral finance, including Odean (1999) and Barber and Odean (2000, 2002), shows that overconfident investors trade too often. From this perspective, it is possible that overconfidence leads investors to trade too often in the domestic market and motivates them to start investing abroad in their quest for new trading opportunities. If this is the explanation for our finding, then we expect the interactions with LTRADES in the previous tests to be insignificant since there is no apparent reason for overconfidence to correlate with investors' education or financial knowledge. Further, those interactions should also lose their significance once we control for overconfident investors. To this end, we repeat the previous tests after we control for overconfident investors, which we identify through the dummy variable OVERCONFIDENCE. We follow Goetzmann and Kumar (2008) and Bailey et al. (2008) and classify an investor as overconfident if his trading activity is in the top quartile of the distribution on investors' trading activity and his performance is in the bottom quartile of the distribution on investors' performance.

Finally, we attempt to disentangle these two explanations for our finding by investigating the performance of investors after they start investing abroad. Following Odean (1999) and Barber and Odean (2000) finding that overconfident investors tend to underperform, we hypothesize that if overconfidence is the reason why active investors in the domestic market start to invest in foreign securities earlier, then their performance should remain unchanged after they enter the foreign market. In contrast, if investors learn while they trade in the domestic market and this drives them to start investing in foreign securities then we should observe an improvement in the performance of these investors. We use standard multivariate analysis to investigate if investors' entry to the foreign markets improves their performance. We review our data sources next.

\subsection{Data}

Our main data source is a proprietary database made available to us by one of the largest Portuguese banks containing the history of individual investors' trades in securities and mutual funds over a decade. The database reports detailed socio-economic and financial information on individual investors who traded in securities, including mutual funds, at least once over the period that goes from January 1997 to September of 2006.

Socio-economic information includes investor's age, gender, marital status, home address (zip code), education and employment. With regards to financial information, our database reports information on the assets and liabilities of each investor, including information on whether the investor has a savings account, personal loans and mortgages, and detailed information on the trading activity of each investor. 
Table 1

Sample characterization: Who invests abroad? ${ }^{\mathrm{a}}$

\begin{tabular}{|c|c|c|c|c|}
\hline \multirow[t]{2}{*}{ Variables } & \multicolumn{2}{|c|}{ Investors who invest in: } & \multirow[t]{2}{*}{ Difference } & \multirow[t]{2}{*}{ T Statistic } \\
\hline & Domestic securities & Foreign securities & & \\
\hline \multicolumn{5}{|l|}{ A: Investors' characteritics } \\
\hline$M A L E$ & 65.9 & 84.4 & -18.6 & $-29.52^{* * *}$ \\
\hline$A G E$ & 50 & 50 & 0 & -0.13 \\
\hline MARRIED & 65.7 & 62.5 & 3.2 & $3.85^{* * *}$ \\
\hline \multicolumn{5}{|l|}{ Education } \\
\hline BASIC EDU & 17.8 & 6.9 & 10.9 & $19.62^{* * *}$ \\
\hline INTERMEDIATE EDU & 46.7 & 34.9 & 11.8 & $11.51^{* * *}$ \\
\hline HIGH EDU & 35.6 & 58.2 & -22.6 & $-21.43^{* * *}$ \\
\hline \multicolumn{5}{|l|}{ Employment } \\
\hline INACTIVE & 21.2 & 14.2 & 6.9 & $11.34^{* * *}$ \\
\hline SKILLED & 26.3 & 15.6 & 10.7 & $16.78^{* * *}$ \\
\hline HIGHLY SKILLED & 52.5 & 70.1 & -17.6 & $-22.04^{* * *}$ \\
\hline \multicolumn{5}{|l|}{ Residence } \\
\hline LISBON & 26.5 & 36.2 & -9.6 & $-11.69^{* * *}$ \\
\hline OPORTO & 13.7 & 14.1 & -0.4 & -0.67 \\
\hline OTHER & 51.1 & 41.8 & 9.3 & $10.96^{* * *}$ \\
\hline TIME DEPOSIT & 23.3 & 31.7 & -8.4 & $-10.49^{* * *}$ \\
\hline MORTGAGE & 17.1 & 15.1 & 2.0 & $3.26^{* * *}$ \\
\hline CONSUMER LOAN & 9.8 & 8.3 & 1.5 & $3.12^{* * *}$ \\
\hline LITERACY & 3.9 & 8.1 & -4.2 & $-8.85^{* * *}$ \\
\hline \multicolumn{5}{|l|}{ B: Portfolio composition (\%) } \\
\hline DERIVATIVES & 5.9 & 6.5 & -0.6 & -1.40 \\
\hline MUTUAL FUNDS ${ }_{D}$ & 21.7 & 45.6 & -24.0 & $-28.12^{* * *}$ \\
\hline MUTUAL FUNDS $_{F}$ & 1.8 & 16.9 & -15.1 & $-23.71^{* * *}$ \\
\hline \multicolumn{5}{|c|}{ C: Trading history: Annual average number of trades $i^{\mathrm{b}}$} \\
\hline SECURITIES $_{D}$ & 1.46 & 14.83 & -13.37 & $-23.53^{* * *}$ \\
\hline MUTUAL FUNDS $S_{D}$ & 1.23 & 5.44 & -4.21 & $-6.61^{* * *}$ \\
\hline$M_{U T U A L} F U N D S_{F}$ & 1.09 & 5.02 & -3.93 & $-17.39^{* * *}$ \\
\hline \multicolumn{5}{|l|}{ D: Investors' performance ${ }^{\mathrm{c}}$} \\
\hline Before investing abroad & $-0.024^{\mathrm{d}}$ & -0.020 & -0.004 & $-4.28^{* * *}$ \\
\hline After investing abroad & & -0.013 & & \\
\hline Difference & & -0.007 & & \\
\hline T Statistic & & $-5.48^{* * *}$ & & \\
\hline
\end{tabular}

*, ${ }^{* *}$ and ${ }^{* * *}$ denote statistical significance at $10 \%, 5 \%$ and $1 \%$, respectively.

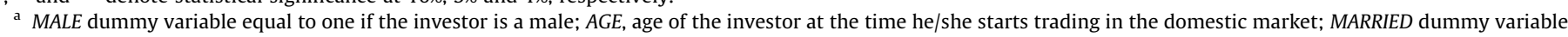

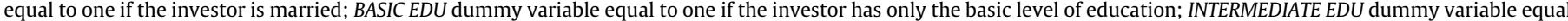

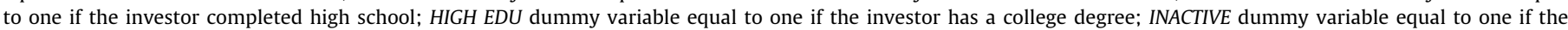

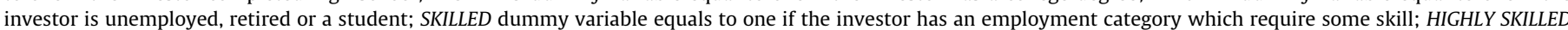

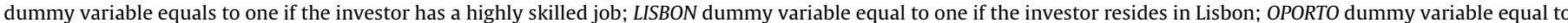

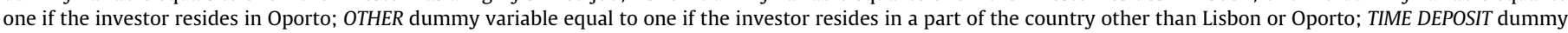

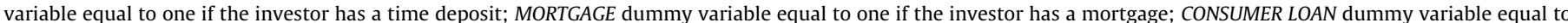

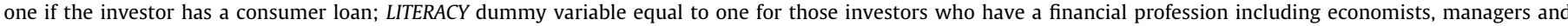

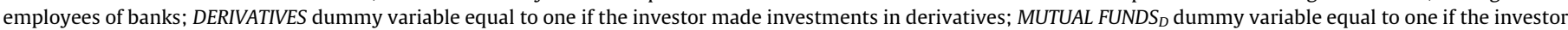

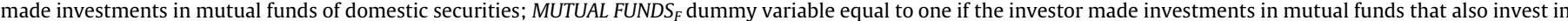

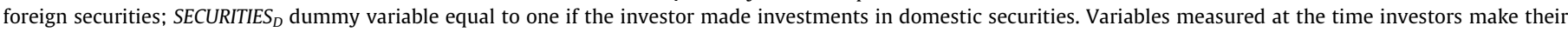
first investment in foreign securities or at the end of the sample for those investors that never invest in foreign securities, unless we indicate otherwise.

b Averages computed over the entire sample period.

c Performance measured by the 30-day average return of stocks purchased in each quarter.

d To be more precise, this measures the performance over the entire sample period of investors that never invest in foreign securities.

The database reports for each trade, the date of the transaction, the type of transaction (buy or sell), the price, the number of securities traded, and the description of the asset (ISIN code and name of asset). ${ }^{16}$ We use this description of assets to distinguish trades in domestic assets from those in foreign assets, and to identify trades that are in stocks, bonds, derivatives and mutual funds. We also use that information to distinguish direct investments in foreign securities listed outside Portugal from investments in securities of foreign firms that are listed in the Portuguese stock market. Since we want to focus on investors' decision to enter abroad by making investments in foreign securities listed outside their home country, we drop from our sample investors who make investments in securities of foreign firms listed in the Portuguese stock market. This

\footnotetext{
${ }^{16}$ We use Bloomberg to get future price information on the securities traded by our investors.
}

alternative avenue to invest in foreign securities is not relevant for Portuguese investors since during the sample period there are only 3 foreign firms listed in the Lisbon Stock Exchange.

Finally, by combining this information on the trading activity of investors with data from the Information Disclosure System of the Portuguese Securities Commission (CMVM), which describes the asset composition of each mutual fund, we are able to identify investors who invest in foreign securities through mutual funds. We do not consider these investments to determine when an investor first invests abroad in part because it is not entirely clear that investors are aware of that particular aspect of mutual funds. Quite often the selection of the mutual fund is made by an adviser at the bank as opposed to a choice of the investor. At any rate, as we noted above, we control for investors that make investments in foreign mutual funds in our duration analysis. 
Table 2

Determinants of investors' first investment in foreign securities. ${ }^{\mathrm{a}}$

\begin{tabular}{|c|c|c|c|c|c|c|}
\hline Variables & (1) & (2) & (3) & (4) & (5) & (6) \\
\hline LTRADES & $\begin{array}{l}0.539^{* * *} \\
(36.62)\end{array}$ & $\begin{array}{l}0.532^{* * *} \\
(36.09)\end{array}$ & $\begin{array}{l}0.526^{* * *} \\
(35.34)\end{array}$ & $\begin{array}{l}0.527^{* * *} \\
(35.34)\end{array}$ & $\begin{array}{l}0.525^{* * *} \\
(35.17)\end{array}$ & $\begin{array}{l}0.524^{* * *} \\
(35.08)\end{array}$ \\
\hline MARRIED & $\begin{array}{l}-0.194^{* * *} \\
(4.88)\end{array}$ & $\begin{array}{l}-0.183^{* * *} \\
(4.61)\end{array}$ & $\begin{array}{l}-0.183^{* * *} \\
(4.50)\end{array}$ & $\begin{array}{l}-0.183^{* * *} \\
(4.50)\end{array}$ & $\begin{array}{l}-0.177^{* * *} \\
(4.35)\end{array}$ & $\begin{array}{l}-0.177^{* * *} \\
(4.35)\end{array}$ \\
\hline MALE & $\begin{array}{l}0.556^{* * *} \\
(11.13)\end{array}$ & $\begin{array}{l}0.540^{* * *} \\
(10.79)\end{array}$ & $\begin{array}{l}0.521^{* * *} \\
(10.11)\end{array}$ & $\begin{array}{l}0.520^{* * *} \\
(10.08)\end{array}$ & $\begin{array}{l}0.529^{* * *} \\
(10.25)\end{array}$ & $\begin{array}{l}0.529^{* * *} \\
(10.24)\end{array}$ \\
\hline$A G E$ & $\begin{array}{l}-0.006^{* * *} \\
(4.82)\end{array}$ & $\begin{array}{l}-0.004^{* * *} \\
(2.71)\end{array}$ & $\begin{array}{l}-0.005^{* * * *} \\
(3.47)\end{array}$ & $\begin{array}{l}-0.005^{* * *} \\
(3.48)\end{array}$ & $\begin{array}{l}-0.006^{* * *} \\
(3.96)\end{array}$ & $\begin{array}{l}-0.006^{* * *} \\
(3.96)\end{array}$ \\
\hline LISBON & $\begin{array}{l}0.369^{* * *} \\
(9.57)\end{array}$ & $\begin{array}{l}0.292^{* * *} \\
(7.45)\end{array}$ & $\begin{array}{l}0.284^{* * *} \\
(7.17)\end{array}$ & $\begin{array}{l}0.284^{* * *} \\
(7.17)\end{array}$ & $\begin{array}{l}0.284^{* * *} \\
(7.16)\end{array}$ & $\begin{array}{l}0.284^{* * *} \\
(7.17)\end{array}$ \\
\hline OPORTO & $\begin{array}{l}0.097^{*} \\
(1.83)\end{array}$ & $\begin{array}{l}0.043 \\
(0.80)\end{array}$ & $\begin{array}{l}0.024 \\
(0.44)\end{array}$ & $\begin{array}{l}0.022 \\
(0.41)\end{array}$ & $\begin{array}{l}0.019 \\
(0.35)\end{array}$ & $\begin{array}{l}0.019 \\
(0.35)\end{array}$ \\
\hline HIGH EDU & & $\begin{array}{l}0.787^{* * *} \\
(8.65)\end{array}$ & $\begin{array}{l}0.705^{* * *} \\
(7.54)\end{array}$ & $\begin{array}{l}0.702^{* * *} \\
(7.50)\end{array}$ & $\begin{array}{l}0.707^{* * *} \\
(7.55)\end{array}$ & $\begin{array}{l}0.706^{* * *} \\
(7.54)\end{array}$ \\
\hline INTERMEDIATE EDU & & $\begin{array}{l}0.388^{* * * *} \\
(4.16)\end{array}$ & $\begin{array}{l}0.367^{* * *} \\
(3.88)\end{array}$ & $\begin{array}{l}0.367^{* * *} \\
(3.88)\end{array}$ & $\begin{array}{l}0.375^{* * *} \\
(3.96)\end{array}$ & $\begin{array}{l}0.375^{* * *} \\
(3.95)\end{array}$ \\
\hline HIGHLY SKILLED & & & $\begin{array}{l}0.098^{*} \\
(1.79)\end{array}$ & $\begin{array}{l}0.097^{*} \\
(1.76)\end{array}$ & $\begin{array}{l}0.112^{* *} \\
(2.04)\end{array}$ & $\begin{array}{l}0.112^{* *} \\
(2.04)\end{array}$ \\
\hline SKILLED & & & $\begin{array}{l}-0.237^{* * *} \\
(3.52)\end{array}$ & $\begin{array}{l}-0.237^{* * *} \\
(3.51)\end{array}$ & $\begin{array}{l}-0.230^{* * *} \\
(3.41)\end{array}$ & $\begin{array}{l}-0.230^{* * *} \\
(3.41)\end{array}$ \\
\hline TIME DEPOSIT & & & & $\begin{array}{l}0.038 \\
(0.98)\end{array}$ & $\begin{array}{l}0.053 \\
(1.35)\end{array}$ & $\begin{array}{l}0.052 \\
(1.33)\end{array}$ \\
\hline MORTGAGE & & & & & $\begin{array}{l}-0.187^{* * *} \\
(3.66)\end{array}$ & $\begin{array}{l}-0.187^{\text {**** }} \\
(3.66)\end{array}$ \\
\hline CONSUMER LOAN & & & & & $\begin{array}{l}0.048 \\
(0.74)\end{array}$ & $\begin{array}{l}0.049 \\
(0.75)\end{array}$ \\
\hline EUROPEAN RET & & & & & & $\begin{array}{l}-0.485 \\
(1.49)\end{array}$ \\
\hline $\begin{array}{l}\text { LR }>\chi^{2} \\
\text { HO: proportional hazard }\end{array}$ & 6385 & 6519 & 6374 & 6374 & 6421 & 6421 \\
\hline $\operatorname{Prob}\left(>\chi^{2}\right)$ for $\mathrm{HO}$ & 0.000 & 0.000 & 0.000 & 0.000 & 0.000 & 0.000 \\
\hline Observations & 942887 & 942887 & 914703 & 914703 & 914657 & 914657 \\
\hline Investors & 136166 & 1361666 & 131464 & 131464 & 131452 & 131452 \\
\hline Failures & 3252 & 3252 & 3172 & 3172 & 3172 & 3172 \\
\hline
\end{tabular}

${ }^{*},{ }^{* *}$ and ${ }^{* * *}$ denote statistical significance at $10 \%, 5 \%$ and $1 \%$, respectively.

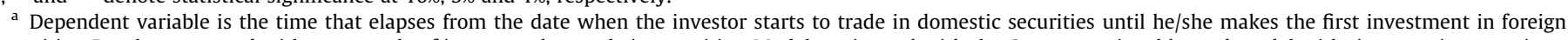

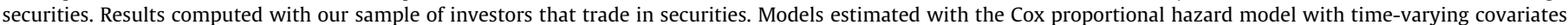

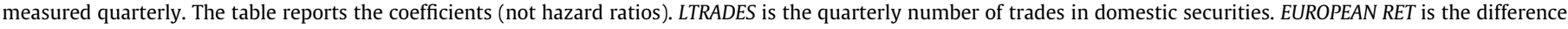
between the return in the European markets and the Portuguese market. See Table 1 for the definitions of the remaining independent variables.

\subsection{Sample characterization}

Our database has information for 918,246 investors. To construct our sample, we begin by dropping from this universe investors who reside abroad as their foreign holdings may have been acquired in their country of residence rather than in Portugal. Next, we drop investors who make investments in the stock of foreign corporations listed in the Portuguese stock exchange since we want to focus on investments in foreign securities made abroad. We further drop investors who do not have any trading activity during the sample period, and investors whose starting trading date was prior to our sample period since we do not have the complete history of their trading activity. Lastly, since we do not have information for all of the investors in our database on the date they opened a trading account with our bank either because this information is missing or because the investor appears in our database as a result of a bank acquisition by our bank, we drop all investors whose first security trade during the sample period is a sale because these investors were already active before the sample period. ${ }^{17}$

That selection criteria leaves us with a sample of 136,166 investors, of which 3252 made their first investment in individual for-

\footnotetext{
17 Most of the investors appear in our database because they are clients of our bank, which is one of the largest banks in the country. Since this bank was involved in some acquisitions during the sample period and it merged the clients of the target banks into its database in some cases we are unable to identify the investor's starting trading date.
}

eign securities during our sample period. This is the sample we consider in our investigation. It is apparent from the composition of our sample that only a small number of investors invest in foreign securities even when we consider their trading activity over a decade, an indication that the home county bias remains a very important problem. Further, even among investors who eventually invest in foreign securities, many of them wait quite some time before they start making these investments confirming that there is a life cycle effect in these investments. Only 650 of those 3252 investors invest in a foreign security in their first year of activity. By the end of the third year of activity about half of them have entered the foreign market, but after five years more than one third of those investors have not still made their first investment in foreign securities.

Of the 3,252 investors who invest abroad for the first time during the sample period, $37.4 \%$ made their first investment in the stock of a German firm, 35.5\% did it in the stock of a Spanish firm, and $11.6 \%$ did it in the stock of an American firm. The remaining investors made their first investment in corporations in such countries as France, the Netherlands, UK, Luxembourg, Finland, among others.

Table 1 compares our sample of investors who enter foreign securities markets with those investors who invest only in domestic securities throughout the sample period (included in the latter are also those investors who have holdings in mutual funds that invest in foreign securities). The top panel of Table 1 shows that investors who are more prone to take risks, male and single investors, are more likely to invest in securities abroad. More educated 
Table 3

Robustness tests. ${ }^{a}$

\begin{tabular}{|c|c|c|c|c|c|}
\hline Variables & (1) & (2) & (3) & (4) & (5) \\
\hline LTRADES & $\begin{array}{l}0.517^{* * *} \\
(34.65)\end{array}$ & $\begin{array}{l}0.528^{* * *} \\
(34.77)\end{array}$ & $\begin{array}{l}0.518^{* * *} \\
(34.80)\end{array}$ & $\begin{array}{l}0.458^{* * *} \\
(29.67)\end{array}$ & $\begin{array}{l}0.525^{* * *} \\
(35.11)\end{array}$ \\
\hline DERIVATIVES & $\begin{array}{l}0.558^{* * *} \\
(6.91)\end{array}$ & & & & \\
\hline MUTUAL FUNDS ${ }_{D}$ & & $\begin{array}{l}-0.063 \\
(1.29)\end{array}$ & & & \\
\hline MUTUAL FUNDS $F$ & & & $\begin{array}{l}0.711^{* * *} \\
(9.87)\end{array}$ & & \\
\hline SPAIN & & & & $\begin{array}{l}2.906^{* * *} \\
(45.64)\end{array}$ & \\
\hline PERFORMANCE $E_{Q 1}$ & & & & & $\begin{array}{l}-0.011 \\
(0.21)\end{array}$ \\
\hline PERFORMANCE $E_{Q 2}$ & & & & & $\begin{array}{l}-0.202^{* * *} \\
(4.01)\end{array}$ \\
\hline PERFORMANCE $E_{Q 3}$ & & & & & $\begin{array}{l}-0.229^{* * *} \\
(4.74)\end{array}$ \\
\hline $\begin{array}{l}\text { LR }>\chi^{2} \\
\text { H0: proportional hazard }\end{array}$ & 6435 & 6421 & 6437 & 7565 & 6471 \\
\hline $\operatorname{Prob}\left(>\chi^{2}\right)$ for $\mathrm{H} 0$ & 0.000 & 0.000 & 0.000 & 0.000 & 0.000 \\
\hline Observations & 914657 & 914657 & 914657 & 914657 & 914657 \\
\hline
\end{tabular}

${ }^{*},{ }^{* *}$ and ${ }^{* * *}$ denote statistical significance at $10 \%, 5 \%$ and $1 \%$, respectively.

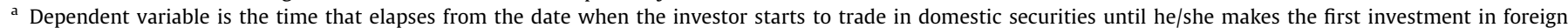

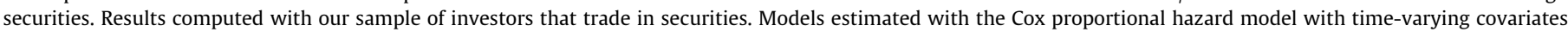

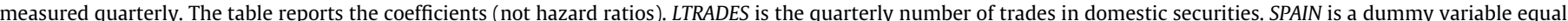

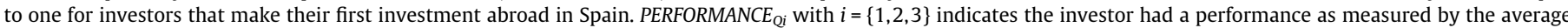

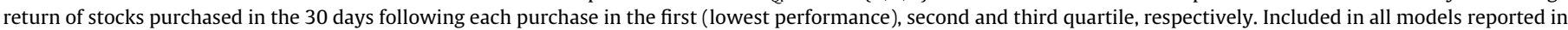
this table are the controls used in model 6 of Table 2. See Table 1 for the definitions of the remaining independent variables.

investors (with a college degree) and investors with more financial knowledge (those with a high level of financial literacy as well as those who invest in derivatives) are also more likely to invest in foreign securities. Wealthier investors (those with highly skilled jobs and those with a time deposit and with no loans) also have a higher probability of investing in foreign securities. Panel $\mathrm{C}$ of that table shows that more active investors in the domestic market are more likely to invest in foreign securities abroad.

Finally, the bottom panel of Table 1 shows that investors who make foreign investments have better investment skills because they outperform the remaining investors. According to our measure of performance, both investors who invest only in domestic securities as well as those who invest in foreign securities have negative returns, but those who make foreign investments have better returns. ${ }^{18}$ Importantly, investors who enter the foreign markets are able to improve on their performance once they start investing in securities abroad.

\section{Investing in foreign securities for the first time}

We present in this section the results of our survival analysis of the length of time it takes an investor to start investing in individual foreign securities. We identify that length of time by the age of the investor's trading account at the time of his first investment in foreign securities and measure that age by the number of days that elapsed since the investor started to invest in individual securities or mutual funds and the date of the investor's first investment in foreign (individual) securities.

Table 2 presents the results of our investigation of the determinants of that age using the Cox proportional hazard model with time-varying covariates. We report the coefficients rather than hazard ratios (exponential coefficients) because our main interest is in the direction of the effects, rather than their magnitude. A po-

\footnotetext{
18 As we explained in the methodology section, since we do not have information on the composition of the portfolios for all investors in our sample, we follow Seru et al. (2008) and measure the performance of investors by the 30-day average return of stocks purchased in each quarter.
}

sitive coefficient indicates that an increase in the associated explanatory variable increases the hazard of the first investment in foreign securities in any given year. In other words, a positive coefficient means the explanatory variable speeds up investors' decision to start investing in foreign securities. Though not included in the table, all of the models are estimated with a set of year dummies to account for potential time effects on investors' decision to go abroad. ${ }^{19}$

A quick look at the first row of Table 2 shows that in all of the models there is a negative correlation between the trading experience of the investor in the domestic market and the length of time it takes the investor to start investing in foreign securities. Investors who are more active in the domestic market, that is, LTRADES is larger, enter foreign markets earlier. Model 1 shows that this association holds when we control for investors' demographical determinants, including their gender, marital status and age, and when we account for their place of residence. According to this model, married and female investors as well as older investors wait a longer period of time before they start investing in foreign securities. These findings are consistent with the literature which finds these investors to be less prone to take on risk. ${ }^{20}$ Still according to model 1, investors who reside in the largest cities (Lisbon and Oporto) are more likely to start investing in foreign securities earlier. This result may be attributable to the additional information available to these investors since financial institutions are predominantly located in these cities. The place of residence could also capture a wealth effect since wealthier investors tend to live in the largest cit-

\footnotetext{
19 These dummy variables are also important to account for potential changes in the way the stock markets operated during the sample period. In 2002, the Portuguese stock market joined the Euronext. This could have affected investors' choice of investments because it allowed Portuguese investors to access foreign securities traded in one of the other four European Euronext markets (Amsterdam, Bruxelles, Paris and UK for derivatives) quicker and at lower cost. We did investigate if the membership of the Portuguese stock exchange in the Euronext had an effect on Portuguese investors' home bias, but we did not find it led to a reduction in the time it takes investors to start investing abroad. This could also be attributed to the fact that most of our sample is for the post Euronext period.

20 See Barber and Odean (2001) and Goetzmann and Kumar (2008) for evidence that married and female and older investors have less appetite for risk.
} 
Table 4

Learning by trading in the domestic market. ${ }^{a}$

\begin{tabular}{|c|c|c|c|c|c|c|c|c|}
\hline Variables & $(1)$ & $(2)$ & (3) & $(4)$ & (5) & (6) & $(7)$ & $(8)$ \\
\hline LTRADES & $\begin{array}{l}0.549^{* * *} \\
(31.84)\end{array}$ & $\begin{array}{l}0.529^{* * *} \\
(34.72)\end{array}$ & $\begin{array}{l}0.543^{* * *} \\
(35.19)\end{array}$ & $\begin{array}{l}0.515^{* * *} \\
(33.19)\end{array}$ & $\begin{array}{l}0.538^{* * *} \\
(30.73)\end{array}$ & $\begin{array}{l}0.518^{* * *} \\
(33.50)\end{array}$ & $\begin{array}{l}0.531^{\text {**** }} \\
(33.86)\end{array}$ & $\begin{array}{l}0.503^{* * *} \\
(31.96)\end{array}$ \\
\hline HIGH EDU & $\begin{array}{l}0.894^{* * *} \\
(7.76)\end{array}$ & $\begin{array}{l}0.682^{* * *} \\
(7.26)\end{array}$ & $\begin{array}{l}0.705^{* * *} \\
(7.53)\end{array}$ & $\begin{array}{l}0.628^{* * *} \\
(6.69)\end{array}$ & $\begin{array}{l}0.868^{* * *} \\
(7.49)\end{array}$ & $\begin{array}{l}0.657^{* * *} \\
(6.99)\end{array}$ & $\begin{array}{l}0.679^{* * *} \\
(7.24)\end{array}$ & $\begin{array}{l}0.604^{* * *} \\
(6.43)\end{array}$ \\
\hline HIGH EDU x LTRADES & $\begin{array}{l}-0.068^{* * *} \\
(2.77)\end{array}$ & & & & $\begin{array}{l}-0.068^{* * *} \\
(2.74)\end{array}$ & & & \\
\hline LITERACY & & $\begin{array}{l}0.471^{* * *} \\
(3.01)\end{array}$ & & & & $\begin{array}{l}0.441^{* * *} \\
(2.77)\end{array}$ & & \\
\hline LITERACY x LTRADES & & $\begin{array}{l}-0.092^{*} \\
(1.90)\end{array}$ & & & & $\begin{array}{l}-0.087^{*} \\
(1.76)\end{array}$ & & \\
\hline DERIVATIVES & & & $\begin{array}{l}0.194 \\
(1.29)\end{array}$ & & & & $\begin{array}{l}0.213 \\
(1.40)\end{array}$ & \\
\hline DERIVATIVES x LTRADES & & & $\begin{array}{l}-0.111^{* * *} \\
(2.59)\end{array}$ & & & & $\begin{array}{l}-0.099^{* *} \\
(2.28)\end{array}$ & \\
\hline SPAIN & & & & $\begin{array}{l}4.986 \text { *** } \\
(37.20)\end{array}$ & & & & $\begin{array}{l}4.880^{* * *} \\
(36.34)\end{array}$ \\
\hline SPAIN x LTRADES & & & & $\begin{array}{l}-0.591^{* * *} \\
(15.00)\end{array}$ & & & & $\begin{array}{l}-0.564^{* * *} \\
(14.29)\end{array}$ \\
\hline OVERCONFIDENCE & & & & & $\begin{array}{l}0.630^{* * *} \\
(12.25)\end{array}$ & $\begin{array}{l}0.626^{* * *} \\
(12.18)\end{array}$ & $\begin{array}{l}0.612^{* * *} \\
(11.90)\end{array}$ & $\begin{array}{l}0.589^{* * *} \\
(11.43)\end{array}$ \\
\hline $\begin{array}{l}\text { LR }>\chi^{2} \\
\text { H0: proportional hazard }\end{array}$ & 6427 & 6432 & 6426 & 7775 & 6437 & 6444 & 6436 & 7890 \\
\hline $\operatorname{Prob}\left(>\chi^{2}\right)$ for $\mathrm{H} 0$ & 0.000 & 0.000 & 0.000 & 0.000 & 0.000 & 0.000 & 0.000 & 0.000 \\
\hline Observations & 914657 & 914657 & 914657 & 91467 & 914657 & 914657 & 914657 & 914657 \\
\hline
\end{tabular}

${ }^{*},{ }^{* *}$ and ${ }^{* * *}$ denote statistical significance at $10 \%, 5 \%$ and $1 \%$, respectively.

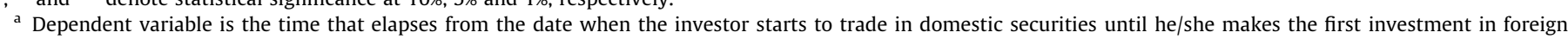

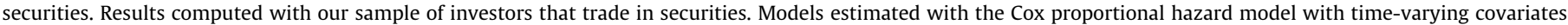

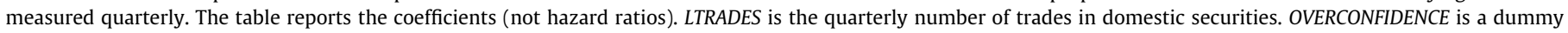

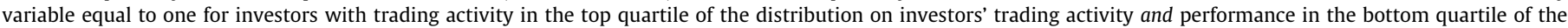

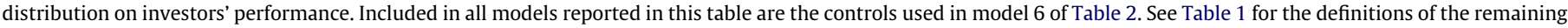
independent variables.

ies or even a financial knowledge effect since jobs in the financial sector are predominantly located in those cities.

In the remaining models of Table 2 , we add sequentially controls for a set of other factors that are likely to affect the timing of investors' decision to start investing abroad. In Model 2 we attempt to control for investors' education by including a set of dummy variables to distinguish investors according to their level of education. The results confirm that investors with more education - those with a college degree, HIGH EDU, as well as those with an intermediate education, INTERMEDIATE EDU - start to invest in foreign securities earlier than investors that only have the basic education (the omitted group).

In Models 3-5 we attempt to control for investors' wealth. In Model 3, we distinguish investors according to their employment. Our results confirm that investors with highly skilled jobs, HIGHLY SKILLED, likely the wealthiest investors, are the first to start investing abroad. Interestingly, skilled workers, SKILLED, are last to enter the foreign markets. This is because our omitted employment category is dominated by retirees, which is likely to include an important share of wealthy investors. In Model 4, we control for investors with a time deposit, TIME DEPOSIT, and in Model 5 we account for investors with mortgages and those with consumer loans, MORTGAGE and CONSUMER LOAN, respectively. The results of these controls confirm our finding that wealthier investors start to invest in foreign securities earlier. ${ }^{21}$ Investors that have mortgages spend more time on the domestic market. In contrast, those with a time deposit enter the foreign securities market earlier, though this difference is not statistically significant.

Finally, in Model 6 we investigate if the performance of the Portuguese stock market plays an important role on the timing of investors' decision to invest abroad. To that end we control for

\footnotetext{
21 This result is consistent with Vissing-Jorgensen's (2003) finding that high wealth households are more likely to invest in foreign securities.
}

EUROPEAN RET, the difference between the return in the European markets and the Portuguese market. Contrary to what one might expect we do not find that the relative performance of the domestic market affects investors' decision to go abroad. It is possible, though, that part of this effect is being picked up by the time dummy variables we have in our models to account for any potential time effects on investors' investment choices.

In sum, this set of results shows that investors who trade more often in the domestic market start to invest in foreign securities earlier than investors who are not very active in the domestic market. Our results also show that this finding is robust to a large set of investor characteristics, including gender, age, place of residence, education, employment and wealth. In the next subsection, we continue our investigation of the robustness of this finding to several other factors that could play a role on investors' decision to start to invest in foreign securities.

\subsection{Robustness tests}

Table 3 presents the results of a set of tests we undertake to investigate the robustness of our key finding. All of the tests are estimated using the controls in Model 6 of Table 2, but in the interest of space we omit these controls and report only the results on our key variable - LTRADES - and the new controls we consider in each test. The first row of Table 3, which reports the coefficient on LTRADES, shows that our finding that investors who trade more often in the domestic market start to invest in foreign securities earlier continues to hold in all robustness tests.

Models 1-3 investigate the importance of three other investment decisions by investors, namely whether they invest in derivatives, DERIVATIVES, whether they invest in mutual funds made of national securities, MUTUAL FUNDS $S_{D}$, and whether they invest in mutual funds made of foreign securities, MUTUAL FUNDS $S_{F}$, respectively. Recall that our measure of investors' trading activity in the 
domestic market considers only trades in stocks and does not account for trades in derivatives or mutual funds. We control for these investment decisions through time-varying dummy variables, that is, they take the value one after the date investors make their investments in each of these assets. ${ }^{22}$ Model 1 shows that investors who invest in derivatives are more likely to start investing in foreign securities earlier, probably because these are the most sophisticated investors. Model 2 shows that investors who invest in national mutual funds tend to wait longer before they invest in foreign securities, though the difference is not statistically significant. In contrast, according to model 3 investors who have holdings of mutual funds made of foreign securities start to invest abroad earlier. Investments in these funds, therefore, function as a complement rather than a substitute for investments in foreign securities.

Model 4 investigates the robustness of our finding when we account for those investors that make their first investment abroad in Spain. Consistent with Beugelsdijk and Frijns (2010) and Anderson et al. (2011) finding that cultural differences influence investors foreign investment choices, our results show that Portuguese investors that make their first foreign investment in Spain do not wait as long as the remaining investors who go abroad, possibly because their cultural affinity with Spain is likely to be high. More importantly, controlling for these investors does not alter our key finding that more active investors in the domestic market enter the foreign market earlier.

Model 5 controls for investors' performance in the domestic market. Investors with a poor performance may have added incentives to start investing abroad in order to improve their performance. On the other hand, investors with a strong performance in the domestic market - most likely those that are most sophisticated - may feel more certain of their capabilities and decide to start to invest abroad earlier. In order to allow for this nonlinear effect of performance, we account for investors' performance in the domestic market through a set of four dummy variables - one for each quartile of the performance distribution. Our results confirm that investors with the weakest performance in the domestic market, PERFORMANCE $E_{Q 1}$, as well as those with the strongest performance, PERFORMANCE $\mathrm{Q}_{4}$ (the omitted category), wait for a shorter period of time before they start to invest abroad.

In addition, we undertake the following robustness tests (results available from the authors upon request). All of the models we report in Tables 2 and 3 are estimated with time-varying covariates taking the quarter as the unit of time. Using instead the year as the relevant unit of time does not change our findings. We consider in our analysis all of the investors who make at least one trade during the sample period. Dropping from the sample less active investors (those that make less than 5 trades over the sample period) affects the significance of some of our covariates but it does not have a material effect on LTRADES.

As we note in the Sample Characterization section, the opening date on the trading account is sometimes missing in our database. In selecting our sample, we drop those investors whose first trade was a sale since this indicates they already had trading activity prior to the beginning of the sample period. This criteria, however, does not rule out the possibility that some of the investors left in the sample may also have had some trading activity before joining our bank. To reduce concerns with these investors we further drop from the sample investors who sell securities that were not acquired during the sample period. Since we have information on investors' trading activity over a ten-year period, we will likely have the entire trading history for the investors that meet this

\footnotetext{
22 Controlling for these investments instead through investors' trading activity (measured by the log of the number of quarterly trades in these assets) yields similar insights and more importantly does not affect our key result that investors who are more active in the domestic market tend to start investing abroad earlier.
}

additional condition. Our key result with regards to the importance of domestic trading on the timing to start investing in foreign securities also holds in this subsample.

Lastly, none of the tests we report thus far address one other potential concern with our sample - the presence of investors with trading accounts in multiple banks. This is more difficult to control for, but we do not expect many investors in our sample to have accounts with another bank. To start with this practice is costly, thereby explaining why so few investors have multiple trading accounts. According to a survey of CMVM (the regulator of the Lisbon Stock Exchange) in 2000, 80.4\% of the investors reported that they had a trading account in only one bank. This practice is likely to be even lower among investors in our sample since they have a trading account with one of the top-three banks in the country that offers a full range of banking and brokerage products.

In conclusion, the evidence we present in this section shows that ceteris paribus investors who trade more often in the domestic stock market wait a shorter period of time before they start to invest in foreign securities. Our results show that this link is robust, but they are silent with respect to the reason(s) behind it. As we discuss in the Introduction, it is unlikely that a strategy that pick stocks randomly explains that link because investors in our sample have to invest abroad in order to invest in foreign securities. This requires a different procedure and it usually entails higher transactions costs. ${ }^{23}$ Instead, active investors may start to invest abroad earlier because they are overconfident and therefore trade too often. Alternatively, these investors enter the foreign market earlier because they learn while they trade in the domestic market and this helps them with their foreign investments. In the next section, we investigate if these hypotheses explain our finding.

\section{Why do active investors start to invest abroad earlier?}

If the reason why active investors in the domestic market enter foreign markets earlier is because they learn while they trade and this helps them to start investing abroad, then highly educated investors and investors with more financial knowledge should not need to trade in the domestic market as much as the remaining investors before they first invest abroad. To investigate this hypothesis, we start by identifying three proxies for investors' education in general and their financial knowledge in particular. The first proxy distinguishes investors who have a college degree, $\mathrm{HIGH}$ $E D U$. Our second proxy distinguishes investors who are more likely to have financial knowledge either because they are economists, managers or employees of banks, LITERACY. Our third proxy distinguishes investors who make investments in derivatives, DERIVATIVES. Since these are usually complex financial instruments, we assume that these investors have more financial knowledge.

To test our hypothesis we interact each of these proxies with investors' trading activity in the domestic market, LTRADES. This interaction term will tell us whether highly educated investors and investors with more financial knowledge need to trade as much in the domestic market as the remaining investors before they start to invest in individual foreign securities.

The results of these tests are in models 1-3 of Table 4 . A quick look at these models reveals two important findings. First, $H I G H$ EDU, LITERACY and DERIVATIVES are all positive and, with the exception of the variable that distinguishes investors who have investments in derivatives, they are all statistically significant.

\footnotetext{
${ }^{23}$ It is more expensive for Portuguese investors to trade foreign securities than domestic securities because Portuguese banks do not have direct access to foreign trading platforms. The bank in our sample offers its customers "homogeneous" trading costs in foreign platforms because of an agreement it has with a foreign financial institution. These costs are nonetheless higher than the fees it charges its customers to trade in the domestic market.
} 
These findings confirm that highly educated investors as well as investors with more financial knowledge do not spend as much time in the domestic market before they start investing abroad. Second, and more importantly, the interaction of these variables with investors' trading activity in the domestic market, LTRADES, is negative and significant in all three models. Thus, everything else equal, more educated investors as well as those with more financial knowledge do not need to trade as much in the domestic market as the remaining investors before they make their first investment abroad.

Model 4 of Table 4 reports the results of the additional test we do based on those investors who make their first investment abroad in Spain. As we note in the Methodology section, since this is the country that Portuguese investors have the highest cultural affinity with, then investors who make their first investment abroad in Spain should not need to learn by trading as much as the remaining investors who go abroad. Consistent with this hypothesis, we find that SPAIN $\times$ LTRADES is negative and statistically significant.

The results of these tests are consistent with the hypothesis that investors learn while they trade in the domestic market and this helps them make the decision to start investing abroad. Further, these results do not appear to be consistent with the hypothesis that active investors start to invest abroad earlier because they are overconfident. While one may argue that overconfidence together with cultural affinity could explain why Portuguese investors do not need to trade as much when they make their first investment abroad in Spain, it is more difficult to argue that overconfidence explains the results of the other tests since there is no apparent reason for overconfidence to correlate with investor's education or financial knowledge. Nonetheless, we investigate next if overconfidence is the key reason why active investors in the domestic market wait for a shorter period of time before they start to invest abroad. To that end, we reestimate models $1-4$ of Table 4 after we control for overconfident investors.

As we explain in the Methodology section, we follow Goetzmann and Kumar (2008) and Bailey et al. (2008) and classify an investor as overconfident if his trading activity is in the top quartile of the distribution on investors' trading activity and his performance is in the bottom quartile of the distribution on investors' performance. The results of these tests are in models 5-8 of Table 4. Since OVERCONFIDENCE is positive and significant in all models, the new results indicate that those investors who are likely to be overconfident wait a shorter period of time before they make their first investment in foreign securities. More importantly, controlling for these investors has no major effect on our earlier findings with regards to more educated and better informed investors as well as investors who make their first investment in Spain. Comparing models 1-4 with models 5-8 of Table 4, it is apparent that controlling for overconfident investors either leaves the interaction variable unaffected or it reduces it only marginally without affecting its statistical significance. These results, therefore, further suggest that overconfidence is not the key reason why investors who are active in the domestic market wait for a shorter period of time before they make their first investment abroad.

\subsection{Do foreign investments improve investors' performance?}

An alternative way to ascertain if learning by trading in the domestic market or overconfidence drives our result on investors' decision to start investing abroad is to investigate their performance afterwards. Following Odean (1999) and Barber and Odean (2000) finding that overconfident investors trade too much and this leads to poor performance, we posit that if the reason why active investors enter the foreign market earlier is because they are
Table 5

Investing in foreign securities and investor performance. ${ }^{a}$

\begin{tabular}{|c|c|c|}
\hline Variables & (1) & (2) \\
\hline EX POST PERFORMANCE & $\begin{array}{l}0.008^{* * *} \\
(5.18)\end{array}$ & $\begin{array}{l}0.009^{* * *} \\
(4.52)\end{array}$ \\
\hline FOREIGN INVESTOR & $\begin{array}{l}0.005^{* * *} \\
(4.51)\end{array}$ & \\
\hline MARRIED & $\begin{array}{r}-0.001 \\
(0.19)\end{array}$ & \\
\hline MALE & $\begin{array}{l}0.004^{* * * *} \\
(6.92)\end{array}$ & \\
\hline$A G E$ & $\begin{array}{l}0.001^{\text {**** }} \\
(4.20)\end{array}$ & \\
\hline LISBON & $\begin{array}{l}0.003^{* * *} \\
(5.74)\end{array}$ & \\
\hline OPORTO & $\begin{array}{l}-0.002^{* * *} \\
(3.22)\end{array}$ & \\
\hline HIGH EDU & $\begin{array}{c}0.002^{*} \\
(1.81)\end{array}$ & \\
\hline INTERMEDIATE EDU & $\begin{array}{r}0.001 \\
(0.52)\end{array}$ & \\
\hline HIGHLY SKILLED & $\begin{array}{r}0.001 \\
(1.09)\end{array}$ & \\
\hline SKILLED & $\begin{array}{r}-0.001 \\
(1.06)\end{array}$ & \\
\hline TIME DEPOSIT & $\begin{array}{l}0.003^{* * *} \\
(5.49)\end{array}$ & \\
\hline MORTGAGE & $\begin{array}{c}-0.002^{* * *} \\
(2.67)\end{array}$ & \\
\hline CONSUMER LOAN & $\begin{array}{c}-0.001^{*} \\
(1.66)\end{array}$ & \\
\hline EUROPEAN RET & $\begin{array}{l}-0.136^{* * *} \\
(23.63)\end{array}$ & $\begin{array}{l}-0.228^{* * *} \\
(29.61)\end{array}$ \\
\hline Constant & $\begin{array}{l}-0.028^{* * *} \\
(19.52)\end{array}$ & $\begin{array}{l}-0.020^{\text {*** }} \\
(72.91)\end{array}$ \\
\hline$R^{2}$ & 0.0026 & 0.3388 \\
\hline Cross-sections included & 129453 & 134951 \\
\hline Total panel (unbalanced) observations & 297933 & 308775 \\
\hline
\end{tabular}

${ }^{*}{ }^{* *}$ and ${ }^{* * *}$ denote statistical significance at $10 \%, 5 \%$ and $1 \%$, respectively.

a Dependent variable is PERFORMANCE as measured by the average return of stocks purchased in the 30 days following each purchase. Results computed with our sample of investors that trade in securities. Model 1 estimated with panel least squares. Model 2 estimated with panel least squares and investor-fixed effects. EX POST PERFORMANCE is a dummy variable equal to one for investors in the time period after they make their first investment in foreign securities. FOREIGN INVESTOR is a dummy variable equal to one for those investors who start to invest in foreign securities during the sample period. See Table 1 for the definitions of the remaining independent variables.

overconfident, then their performance should not improve afterwards. Alternatively, if investors learn as they trade and this helps them go abroad then we should observe an improvement in their performance afterwards.

To investigate this hypothesis, we consider a multivariate model in which the dependent variable is the investor's PERFORMANCE, which we measure following Seru et al. (2008) by the 30-day average return of stocks purchased in each quarter. The independent variables of this model are the explanatory variables we use in our duration analysis. In addition, we add a dummy variable to distinguish those investors who start to invest in foreign securities during the sample period, and a dummy variable to identify the performance of these investors in the time period after they make their first investment in foreign securities. The results of this test are reported as model 1 of Table 5 . They show that investors who make foreign investments on average appear to have better investment skills because they outperform the remaining investors. More importantly, our results show that these investors are able to improve on their performance once they start to invest in foreign securities. This finding is confirmed in model 2 which we estimate with investor-fixed effects to account for other potential relevant characteristics of investors that we do not take into account with our set of controls. 
This improvement in investors' performance after they start to invest in a foreign market runs counter the overconfidence explanation. In contrast, that improvement in performance is consistent with the hypothesis that investors learn while they trade in the domestic market and this experience helps them start making investments abroad.

\section{Final remarks}

In this paper, we investigate whether investors' trading activity in the domestic market helps them first enter foreign markets. Our investigation of the length of time it takes investors to start investing in foreign securities shows that investors who trade more often in the domestic market start to invest abroad earlier. We argue that the experience investors obtain while trading in the domestic market as opposed to overconfidence is the key driver behind that finding.

Our evidence on the dynamics of individuals' investments leading up to their decision to make the first investment abroad is novel and it helps us understand the home country bias. Our finding that investors need to acquire experience in the domestic market before they adventure into the foreign markets adds support to Graham et al.'s (2005) theory that investors are willing to invest in foreign securities only after they feel competent about the benefits and risks involved in these investments. Further, our finding that investors who enter foreign markets are able to improve on their performance confirms that the home country bias is costly, thereby showing that there are benefits for investors from entering the foreign markets earlier.

\section{Acknowledgements}

The authors thank an anonymous referee, Hilla Skiba and seminar participants at the 2009 FMA meetings for useful comments, and Paulo Silva for outstanding research assistance. The views stated herein are those of the authors and are not necessarily those of the CMVM, Federal Reserve Bank of New York, or the Federal Reserve System. CEFAGE-UE is supported by FCT through POCTI of the QCAIII, which is financed by FEDER and Portuguese funds.

\section{References}

Anderson, C.W., Fedenia, M., Hirschey, M., Skiba, H., 2011. Cultural influences on home bias and international diversification by institutional investors. Journal of Banking and Finance 35, 916-934.

Bailey, W.B., Kumar, A., Ng, D., 2008. Foreign investments of US' individual investors: causes and consequences. Management Science 54 (3), 443-459.
Barber, B., Odean, T., 2002. Online investors: do the slow die first? Review of Financial Studies 15 (2), 455-487.

Barber, B., Odean, T., 2001. Boys will be boys: gender, overconfidence, and common stock investment. Quarterly Journal of Economics 116 (1), 261-292.

Barber, B., Odean, T., 2000. Trading is hazardous to your wealth: the common stock investment performance of individual investors. Journal of Finance 55 (2), 773 806.

Baxter, M., Jermann, U.J., 1997. The international diversification puzzle is worse than you think. American Economic Review 87 (1), 170-180.

Beugelsdijk, S., Frijns, B., 2010. A cultural explanation of the foreign bias in international asset allocation. Journal of Banking and Finance 34 (9), 2121 2131.

Campbell, R.A., Krauussl, R., 2007. Revisiting the home bias puzzle: downside equity risk. Journal of International Money and Finance 26 (7), 1239-1260.

Cooper, I., Kaplanis, E., 1994. Home bias in equity portfolios, inflation hedging, and international capital market equilibrium. Review of Financial Studies 7, 45-60.

Coval, J.D., Moskowitz, T.J., 1999. Home bias at home: local equity preference in domestic portfolios. Journal of Finance 54 (6), 2045-2073.

Cox, D., 1972. Regression models and life-tables. Journal of the Royal Statistical Society $34,187-220$.

French, K., Poterba, J., 1991. Investors diversification, and international equity markets. American Economic Review 81, 222-226.

Goetzmann, W., Kumar, A., 2008. Equity portfolio diversification. Review of Finance 12 (3), 433-463.

Graham, J.R., Harvey, C.R., Huang, H., 2005. Investor competence, trading frequency, and home bias. NBER Working paper 11426

Helpman, E., Melitz, M.J., Yeaple, S.R., 2004. Export versus FDI with heterogeneous firms. American Economic Review 94 (1), 300-316.

Huberman, G., Sengmuller, P., 2004. Performance and employer stock in 401(k) plans. Review of Finance 8 (3), 403-443.

Johanson, J., Vahlne, J-E., 1977. The internationalization process of the firm A model of knowledge development and increasing market commitments. Journal of International Business Studies 8, 23-32.

Kang, J., Stulz, R.M., 1997. Why is there a home bias? An analysis of foreign portfolio equity ownership in Japan. Journal of Financial Economics 46 (1), 3-28.

Karlsson, A., Norden, L., 2007. Home sweet home: home bias and internationa diversification among individual investors. Journal of Banking and Finance 31 (2), 317-333

Kho, B., Stulz, R.M., Warnock, F.E., 2009. Financial globalization, governance and the evolution of the home bias. Journal of Accounting Research 47 (2), 597-635.

Lancaster, T., 1990. The Econometric Analysis of Transition Data: An Econometric Society Monograph. Cambridge University Press, United Kingdom.

Levy, H., Sarnat, M., 1970. International diversification of investment portfolios. American Economic Review 60, 668-675.

Lewis, K., 1999. Trying to explain home bias in equities and consumption. Journal of Economic Literature 37, 571-608

Nicolosi, G., Peng, L., Zhu, N., 2009. Do individual investors learn from their trading experience? Journal of Financial Markets 12 (2), 317-336.

Odean, T., 1999. Do investors trade too much? American Economic Review 89, 1279-1298.

Oehler, A., Rummer, M., Wendt, S., 2008. Portfolio selection of German investors: on the causes of home-biased investment decisions. Journal of Behavioral Finance 9 (3), 149-162.

Seru, A., Shumway, T., Stoffman, N., 2008. Learning by Trading. SSRN: <http:// ssrn.com/abstract $=891694>$.

Strong, N., Xu, X., 2003. Understanding the equity home bias: evidence from survey data. Review of Economics and Statistics 85 (2), 307-312.

Vissing-Jorgensen, A., 2003. Perspectives on behavioral finance: Does 'irrationality' disappear with wealth? Evidence from Expectations and Actions. NBER Macroeconomics Annual. 